\title{
Research on Emotional Adjustment Effect of Sports Game on the Primary and Middle School Students
}

\author{
Hong Zhang \\ Physical Institute \\ Sichuan Normal University \\ Chengdu, Sichuan, China \\ e-mail: hongzh80@163.com
}

\author{
Jianrong Zhang \\ Physical Institute \\ Sichuan Normal University \\ Chengdu, Sichuan, China \\ e-mail: 397641818@qq.com
}

\begin{abstract}
Objectives: To discuss on the effects of emotion regulation on primary and middle school students with sports games. Methods: 12 schools' test Action Emotional Stability Test in the detection result is emotionally unstable 98 middle school students as research subjects, which were intervened for 60 days with sports game, no less than 60 minutes a day sports games after experimental intervention,and adopt Action Emotional Stability Test to measure the emotional stability of 98 students. Result: The study showed the emotion improved with Sports games on students of primary and middle school, Emotional adjustment effect, the willingness of games' participate and feeling of sports games showed high correlation.
\end{abstract}

Keywords-sports games; emotional adjustment; willingness of participation

\section{PREFACE}

The sports games is a comprehensive collective activities, intelligence, ability as a whole, is a kind of using your intelligence, thinking, imagination and creation and other components in one, is a complicated puzzle activities of the psychological and thinking process [1]. The psychological effect of sports games is gradually concerned by the people because of its access standards low, and life integration. The part of empirical research about sports games showed it played a positive role of in psychological adjustment and rehabilitation[2] [3]. Emotion as an important content of the individual psychological health, whether the sports game has also the corresponding emotion regulation function? This article intends to reflect on this issue.

Sports games and activities for primary and secondary students with the possibility of emotion regulation is reflected in: First of all, sports games, activities simply because the required materials, content, learn, species-rich, diverse game play, and low access standards, it is widely loved by the people, also has popularized the reality. Secondly, in sports activities and games, players can spontaneously organize and control activities and games, the initiative to enter the games. Third, in the sports game activities both physical exercise, but also to develop the mind, and easy fun and challenges in the scene, in the active participation of the player in the physical and mental mold. Fourth, sports games not only independent of time, space, content, form and other conditions limiting flexibility and teaching the game time is short, the player has little influence cultural level, but also through the transformation of local conditions and compose in the content, form try on innovation. Sports games and activities both in the content of one of the comprehensive development of students, but also their everyday lives highly recognized entertainment.

\section{OBJECT AND METHOD OF STUDY TYPE STYLE AND FONTS}

\section{A. The object of study}

In a city were randomly selected from 6 middle schools and 6 elementary schools, where school students participated in the experiment, students filled out the Action Emotional Stability Test [4], if students were in dimension scores more than 3 questionnaire the unstable range as experimental object. Specific for inferiority scores below 21 points; depression score less than 22 points; anxiety scores more than 16 points; obsessive-compulsive disorder scores more than 10 points; dependence dimension score less than 20 points; hypochondria dimensions higher than 6 points; the guilt dimension scores higher than 8 points; measurement work through for 1 weeks first, selection of Junior high school students participated in the experiment 51, students 47 people, 43 of whom were male, 55 female .

\section{B. Research Methods}

Emotional stability, refers to an individual in the setbacks situation, can withstand the attack and pressure, there is no escape and overcome the difficulties and to avoid a tolerance of psychological and behavioral disorders. The frustrated reaction of schoolchildren is manifested in the emotional reactions and rational response to these two categories, which the center is emotional tension emotional and stability of individual. Therefore, this study adopts Action Emotional Stability Test [4], it consists of inferiority, depression, anxiety, obsessive-compulsive disorder, dependent, hypochondria concept and guilt form 7 aspects.30 questions every aspect of 210 questions. Each question with "Yes", "No" and 
"hard to say" answer, every aspect has corresponding scorecard. Among them, the sense of inferiority: 6 to 21 are divided into emotional instability, 22 to 30 are divided into emotional adaptability; depressed areas: 7 to 22 are divided into emotional instability, 23 to 30 are divided into emotional adaptability; anxiety aspects: $30 \sim 16$ is divided into emotional instability, 15 to 1 is divided into emotional adaptability; obsessive-compulsive disorder: the 25 to 10 are divided into emotional instability, 9 to 1 is divided into emotional adaptability; dependent areas: 5 to 20 are divided into emotional instability, 21 to 29, divided into emotional adaptability; hypochondriac idea: the $21 \sim 6$ into emotional instability, 5 to 1 is divided into emotional adaptability; guilt aspects of guilt: $23 \sim 8$ divided emotional instability, 7 to 1 is divided into emotional adaptability.

The students fill in Action Emotional Stability Test to obtain their pretest scores registration, according to the pre-test scores to determine whether as the experimental object, and divided into group of primary and middle school, the students 1 hours a day, for 60 consecutive days of sports games experimental intervention, game time in the afternoon between 3-5 implementation, the specific content of sports game is in reference to many of the sports game teaching material, and prepared in sports under the guidance of experts, see table 1.

TABLE I. SPORTS GAME ACTIVITIES

\begin{tabular}{|c|c|c|}
\hline Time & Game content & purpose of the game \\
\hline First week & $\begin{array}{l}\text { 1.make concerted efforts; } 2 \\
\text { cross relay; } 3 \text { Hippie skin } \\
\text { suction; }\end{array}$ & $\begin{array}{l}\text { E Experience the } \\
\text { importance } \\
\text { cooperation }\end{array}$ \\
\hline second week & $\begin{array}{l}\text { 1. Sit up; } 2 \text {. Bunny; } 3 \text { ball } \\
\text { head faster than; }\end{array}$ & $\begin{array}{l}\text { experience the joy of } \\
\text { collaboration }\end{array}$ \\
\hline third week & $\begin{array}{l}\text { 1. Clap unreported } \\
\text { number; 2. Rhythm jump; } \\
\text { 3. Firecrackers }\end{array}$ & $\begin{array}{l}\text { Experience the focus } \\
\text { and concentrate }\end{array}$ \\
\hline fourth week & $\begin{array}{l}\text { 1. Tear; 2. Collective over } \\
\text { obstacles; } 3 \text { three ball is } \\
\text { not normalization }\end{array}$ & $\begin{array}{lr}\text { experience } & \text { the } \\
\text { importance } & \text { of } \\
\text { communication } & \end{array}$ \\
\hline fifth week & $\begin{array}{l}\text { 1. Dragon Boat races; } 2 \\
\text { balloon blowing; } 3 \text {. Trust } \\
\text { Journey }\end{array}$ & $\begin{array}{lr}\text { experience } & \text { the } \\
\text { diversity } & \text { of } \\
\text { communication } & \\
\end{array}$ \\
\hline sixth week & $\begin{array}{l}\text { I.I was wrong; } 2 \text {.Centipede } \\
\text { walk; } 3 \text { back-player }\end{array}$ & $\begin{array}{l}\text { experience to take } \\
\text { responsibility and the } \\
\text { happy }\end{array}$ \\
\hline Seventh week & $\begin{array}{l}\text { 1. Confidence fell back; } 2 \text {. } \\
\text { Blast Supergrass; } 3 \text {. Across } \\
\text { the barrier }\end{array}$ & $\begin{array}{l}\text { experience trust, } \\
\text { tolerance, strength }\end{array}$ \\
\hline eighth week & $\begin{array}{l}\text { 1. Turning leaves; } 2 . \\
\text { Knots; } 3 \text {. Frog jumping }\end{array}$ & $\begin{array}{l}\text { experience relaxed } \\
\text { and confident }\end{array}$ \\
\hline ninth weeks & $\begin{array}{l}\text { 1. review Game 2. "Family } \\
\text { that all love each other " } \\
\text { dance }\end{array}$ & $\begin{array}{l}\text { ended, } \\
\text { harvest }\end{array}$ \\
\hline
\end{tabular}

The weekly game includes 3 activities, preparatory work required to implement each game before the teacher do the site equipment, before the name of the game, the teacher explained the process and rules, requirements and results, and make the necessary demonstration, students make the warm-up activities. Every challenge activities require students to encourage mutual benefit by mutual discussion on this team win method, activity way, after the activity to share activities in the experience, and homework -- on the activity of writing experience,. 60 days later, the experimental object to retest it Action Emotional Stability Test.

The template is used to format your paper and style the text. All margins, column widths, line spaces, and text fonts are prescribed; please do not alter them. You may note peculiarities. For example, the head margin in this template measures proportionately more than is customary. This measurement and others are deliberate, using specifications that anticipate your paper as one part of the entire proceedings, and not as an independent document. Please do not revise any of the current designations.

\section{Statistical Methods}

Application of SPSS12.0 software for T test, X2 test on the relevant data.

\section{RESULTS AND ANALYSIS}

\section{A. Subjective feelings of students to participate in sports games}

TABLE I. THE WISHES AND FEELINGS OF PARTICIPATING IN SPORTS GAMES

\begin{tabular}{|l|c|c|c|}
\hline Feeling of game & total (\%) & Middle(\%) & Primary (\%) \\
\hline $\begin{array}{l}\text { participate in } \\
\text { actively }\end{array}$ & 67 & 59 & 73 \\
\hline $\begin{array}{l}\text { participate } \\
\text { comfortably }\end{array}$ & 84 & 83 & 86 \\
\hline time is too fast & 91 & 93 & 90 \\
\hline $\begin{array}{l}\text { feel happy after } \\
\text { Participation }\end{array}$ & 87 & 81 & 93 \\
\hline
\end{tabular}

Table 2 is the average proportion of subjective feeling to participate in sports game table. which is a total of 7 from the third weeks to the end of the game. After the third week, $67 \%$ of the students actively want to participate in sports games, it is more strongly to participate, indicating Sports games for them are quite attractive compared to middle school students a more active participation in sports games. Participate in sports activities and games make 87 percent of students happy, $84 \%$ of the students feel comfortable, $91 \%$ of students feel the time flies during sports games. Combing student of the game experiences found that subjective feelings of students overall game is better than junior high school students, but the difference of the middle and primary school students on all of these projects were not significantly . Students' subjective experience in sports games sports games more because of good fun and challenging, and students in sports activities and games are easily reached into ecstasy state, so as to obtain this high degree of investment experience pleasure, achieve the negative emotions regulation, for a lot of psychological pressure adjustment. These results reflect the students for sports activities and games of the more 
highly recognized students in the game got more benign emotional experience, and further affirmed it is right for the topics to select sports games as a means of emotional adjustment.

B. The situation of improving emotion with sports games for primary and junior high school students

1) The overall situation of students' mood improvement before and after the experiment.

TABLE II. THE OVERALL SITUATION OF EACH DIMENSION OF EMOTIONAL STABILITY BEFORE AND AFTER THE EXPERIMENT

\begin{tabular}{|l|l|l|}
\hline & before (\%) & after (\%) \\
\hline inferiority & 76 & 63 \\
\hline depression & 78 & $59^{*}$ \\
\hline anxiety & 77 & $40^{*}$ \\
\hline $\begin{array}{l}\text { obsessive-compulsive } \\
\text { disorder }\end{array}$ & 73 & 62 \\
\hline dependent & 79 & $59^{*}$ \\
\hline hypochondria concept & 71 & $43^{*}$ \\
\hline guilt & 76 & 64 \\
\hline
\end{tabular}

(** Indicates $\mathrm{P}<0.001, *$ indicates $\mathrm{P}<0.05$ )

Through the comparison of the experiments' data in" Action Emotional Stability Test " before and after the game, overall, the experimental effects of the sports games in depression, anxiety, dependency, hypochondria concept and other dimensions reflect more obvious, the different of measurement data were significantly before and after sports games in these dimensions. The inferiority, obsession, guilt and other aspects than previously also has a great degree of improvement, the student's emotional state is gradually restored state, indicating sports games have effect of the emotional improvement for primary and middle school students.

2) The comparison of the status of improve emotional before and after .

Table 3 shows the overall trend is the emotion gradually rehabilitation experimental students. Then emotional rehabilitation process, whether the emotion regulation showed grade differences in sports games? Table 4 shows, sports games on pupils 'emotional reactions in the regulation of anxiety, hypochondria concept, depression, inferiority dimensions, It's a greater decline of the proportion of their students before the game; junior high school students' anxiety, dependence, hypochondria concept dimensions of the concept of the regulation effect is more obvious.

TABLE III. THE OVERALL SITUATION OF EACH DIMENSION OF EMOTIONAL STABILITY ON STUDENTS OF PRIMARY AND MIDDLE SCHOOL

\begin{tabular}{|l|c|c|c|c|}
\hline & \multicolumn{2}{|c|}{ Primary } & \multicolumn{2}{c|}{ Middle } \\
\hline & $\begin{array}{c}\text { Before } \\
\text { (\%) }\end{array}$ & $\begin{array}{c}\text { after } \\
\text { (\%) }\end{array}$ & $\begin{array}{c}\text { before } \\
\text { (\%) }\end{array}$ & $\begin{array}{c}\text { after } \\
\text { (\%) }\end{array}$ \\
\hline inferiority & 75 & $58 *$ & 79 & 66 \\
\hline depression & 76 & $53^{*}$ & 82 & 61 \\
\hline anxiety & 71 & $43^{*}$ & 79 & $37 *$ \\
\hline $\begin{array}{l}\text { obsessive- } \\
\text { compulsive } \\
\text { disorder }\end{array}$ & 64 & 57 & 78 & 69 \\
\hline
\end{tabular}

\begin{tabular}{|l|c|c|c|c|}
\hline dependent & 86 & 61 & 73 & $58 *$ \\
\hline $\begin{array}{l}\text { hypochondria } \\
\text { concept }\end{array}$ & 73 & $49 *$ & 64 & $33 *$ \\
\hline guilt & 72 & 62 & 79 & 68 \\
\hline
\end{tabular}

3) Relationship between embeddedness of the sport game and effect of emotional adjustment.

TABLE IV. LIST RELEVANT RESULTS OF SPORTS GAMES IN ALL DIMENSIONS AND EMOTIONAL STABILITY.

\begin{tabular}{|l|c|c|c|c|}
\hline & desire & feeling & items & form \\
\hline inferiority & $0.029^{*}$ & $0.035^{*}$ & 0.72 & 0.728 \\
\hline depression & $0.014^{*}$ & $0.048^{*}$ & 0.359 & 0.089 \\
\hline anxiety & $0.003^{* *}$ & $0.045^{*}$ & 0.646 & 0.936 \\
\hline $\begin{array}{l}\text { obsessive-compulsive } \\
\text { disorder }\end{array}$ & $0.034^{*}$ & 0.069 & 0.318 & 0.182 \\
\hline dependent & $0.030^{*}$ & $0.036^{*}$ & 0.374 & 0.274 \\
\hline hypochondria concept & $0.000^{* *}$ & $0.044^{*}$ & 0.518 & 0.421 \\
\hline guilt & $0.004^{* *}$ & $0.035^{*}$ & 0.193 & 0.873 \\
\hline
\end{tabular}

(** Indicates $\mathrm{P}<0.001$, * indicates $\mathrm{P}<0.05$ )

For the participants of the games 98 experimental students, different grades and genders willingness to participate in the game actively as well as other aspects of the game feel a degree of difference (the difference that the player embed the different levels of the game), and the individual who embedded on the deeper level of sports games whose emotion changes sooner from the student's subjective feelings after the game and emotional stability of each dimension correlation analysis of data obtained,. Statistics show (see Table 5),

It's not significant correlation between the dimensions of emotional stability and the form and items of sports game, but they are relevance between the willingness to participate in the game, the feeling of game and the dimension of motional stability, especially students of strongly games' will, and its various dimensions of emotional stability are significantly correlated, which fully shows that the experiment in sports games to institutionalize executive order for students to participate in sports games not let the student emotions rehabilitation of critical, more importantly, allow students to deeply embedded games, willing to participate in games and activities, and can get in the game is always a good feeling, this is regulating their emotions play a significant key factor.

\section{Conclusions and Recommendations.}

Play sports games more than 60 minutes for 60 days, the research of emotional stability carried out the effect of emotional adjustment were good in student of experimental schools . Care and support, encouragement and help, respect and trust, understanding and understand the importance of a conducive interpersonal and communication. This fully shows that in a sports game, students can through contact with each other, exchange, cooperation, countermeasure to strengthen between individuals or groups communicate, realized they are 
important that mutual solidarity, care and support, encouragement and help, respect and trust, understanding and considerate, which conducive to interpersonal relationships and communication. On the other hand, partnership and friend relationship formed between students under the rules and requirements of sports games, which can be widely migrated to individual's daily life and help to adjust negative emotion. At the same time, research the content of sports game for the students' emotional adjustment has good pertinence, make students through the game to exchange, to express their views and suggestions for better design of the game situation and shorten the interpersonal distance between students.

Although the factors that influence the students emotional rehabilitation, there are special cognition such as time, guide (such as teaching) factors, but the sports games will undoubtedly as the rehabilitation of an independent factor on their mood contribute. Based on these conclusions, primary and middle schools should set up a new concept of "fitness", social, the family should pay enough attention to the psychological rehabilitation of students, appropriate to reduce the burden of students, to work out a practical scheme to ensure that students participate in sports exercise and game time, allowing them to experience in the active participation in the game fun, to achieve physical and mental adjustment.

\section{REFERENCES}

[1] Lin Junwei.Sports game theory. [J]. Physical Culture Education, China,pp.103,October 2009

[2] Cai Jiyun,Yang Shaoqing.The Study of Sports Games on Improving College Students Interpersonal Experimental.[J]. Chinese School Health, China, vol. 31, pp. 1516,December 2010

[3] Wang Ping,Bie Yiejun.The Study of Graduating College Sports Games Subhealth Intervention Efficacy [J]. Modern Preventive Medicine, China, vol. 37, pp. 1910, October 2010

[4] Wang Xiangdong . Mental Health Rating Scale Manual [J]. Chinese Mental Health Journal, China, vol. 3, pp. 30-36, March1990 